\title{
Predicting adolescents social skills based on their parents emotional intelligence
}

\author{
Roshanak KHodabakhsh Pirkalani ${ }^{1}$, Fatemeh Amani ${ }^{2}$, Fatemeh Raiisi ${ }^{3}$, Ameneh Hajkaram ${ }^{4}$ \\ 1- Associate Professor, Department of Psychology, Al-Zahra University, Tehran, Iran (Corresponding Author). \\ E-mail: rkhodabakhsh@alzahra.ac.ir \\ 2-Master of General Psychology, Al-zahra University, Tehran, Iran. \\ 3- $\mathrm{PhD}$ in Cognitive Science, Institute of Cognitive Science, Tehran, Iran. \\ 4- PhD in Counseling and Guidance, Islamic Azad University, Abhar, Iran.
}

Received: 20/12/2019

Accepted: 09/02/2020

\begin{abstract}
Introduction: Emotional intelligence and social skills are two intertwined concepts as each person's level of social skills requires emotional intelligence and emotional intelligence also emerges through social skills.

Aim: The purpose of this study was to investigate the relationship between adolescents' social skills and their parents' emotional intelligence and to predict the social skills of these adolescents based on their parents' emotional intelligence among adolescents in Tehran.

Method: The method of this study was descriptive- correlational. The study population consisted of all Tehranian adolescents (13 - 17) whose parents were alive. The sample of this study included 150 adolescents (with their parents) in Tehran who were selected through random cluster sampling. In addition to demographic questionnaire, Inderbitzen and Foster's (1992) adolescents' social skills questionnaire and Goleman's (2001) emotional intelligence questionnaire were used. Descriptive statistics indices (mean and standard deviation) and multivariate regression analysis were used for data analysis by SPSS-22 software.

Results: The results showed that there is a significant relationship between adolescent's social skills and their parents' emotional intelligence ( $\mathrm{Sig}=0.05$ ). Moreover, $14.4 \%$ of the variance in adolescent social skills was explained by parents' emotional intelligence. More precisely, according to data regression analysis, $3.9 \%$ of variance in adolescent social skills was estimated by maternal emotional intelligence and $0.5 \%$ of variance by father emotional intelligence.
\end{abstract}

Conclusion: To conclude, it seems that high parental emotional intelligence has a positive and significant relationship with increasing adolescent social skills.

Keywords: Emotional intelligence, Social skills, Adolescents, Parents

How to cite this article : KHodabakhsh Pirkalani R, Amani F, Raiisi F, Hajkaram A. Predicting adolescents social skills based on their parents emotional intelligence. Shenakht Journal of Psychology and Psychiatry. 2020; 7 (1): 141-152 .URL: http://shenakht.muk.ac.ir/article-1-893fa.pdf

Copyright (C) 2018 the Author (s). Published by Kurdistan University of Medical Sciences. This is an open access article distributed under the terms of the Creative Commons Attribution-Non Commercial License 4.0 (CCBY-NC), where it is permissible to download, share, remix, transform, and buildup the work provided it is properly cited. The work cannot be used commercially without permission from the journal. 


\title{
بيشبينى مهارتهاى اجتماعى نوجوانان براساس هوش هيجانى والدين آنها
}

\author{
روشنك خدابخش يِير كلانى '، فاطمه امانى '، فاطمه رئيسى'، آمنه حاج كرم؟ \\ ا. إنشيار، گروه روانشناسى، دانشكاه الزهرا، تهران، ايران (مولف مسئول). ايميل: rkhodabakhsh@alzahra.ac.ir

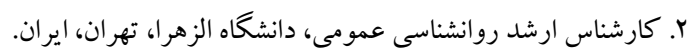 \\ r. ب. دكتراى علوم شناختى، موسسه آموزش عالى شناختى، تهران، ايران.

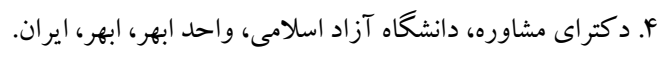

مقدمه: هوش هيجانى و مهارتهاى اجتماعى دو مفهوم درهم تنيدهاى هستند. جر ا كه ميزان مهارتهاى اجتماعى نياز به هوش هيجانى دارد و هوش هيجانى نيز از طريق مهارتهاى اجتماعى ظهور مى مهايد. هدف: يُزوهش حاضر، با هدف بررسى رابطه بين مهارتهاى اجتماعى نوجوانان با هوش هيجانى والدين آنها در بين نوجو انان شهر تهران و همجنين، يِشبينى سطح مهارتهاى اجتماعى نوجو انان بر اساس هوش هيجانى والدين آنها انجام شد. روش: روش اين مطالعه توصيفى از نوع همبستخى بود. جامعه اين مطالعه شامل كليه نوجوانان تهرانى (T) تا IV سال) بود كه والدين

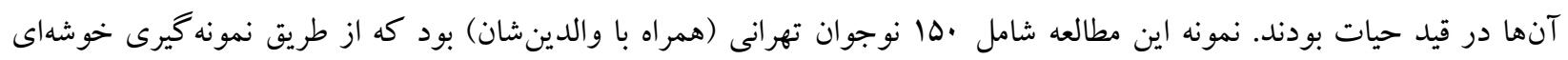

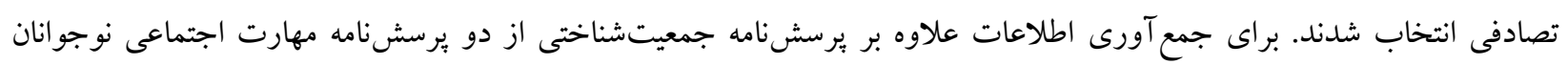

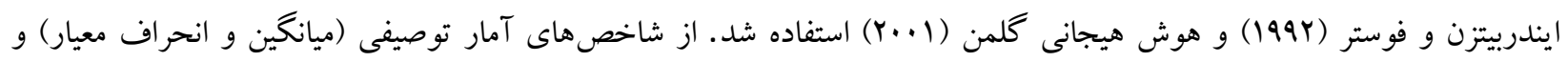

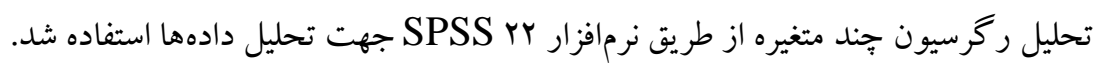
يافتهها: نتايج نشان داد رابطه معنادارى بين سطح مهارتهاى اجتماعى نوجوان و هوش هيجانى والدينشان وجود دارد (در سطح هـ/•). همجنينى، \&/F/ أدرصد از واريانس متغير مهارتهاى اجتماعى نوجوان توسط هوش هيجانى والدين تبيين شد. بهصورت دقيقتر

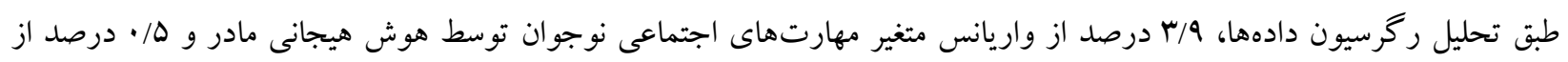
واريانس توسط هوش هيجانى يدر بر آورد شد.

نتيجه كيرى: بنابراين، مىتوان گفت بالا بودن هوش هيجانى والدين، رابطه مثبت و معنادارى با افزايش سطح مهارتهاى اجتماعى نوجوان دارد. كليدوازهها: مهارتهاى اجتماعى، هوش هيجانى، نوجوان، والدين 


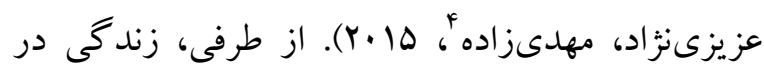
جو امع امروزى بسيار بييجيده شده است و افراد براى ايفاى نقش مؤثر و مفيد علاوه بر مهارتهاى اجتماعى به

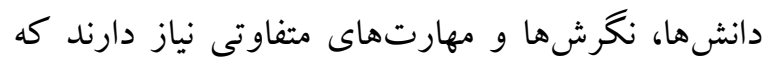

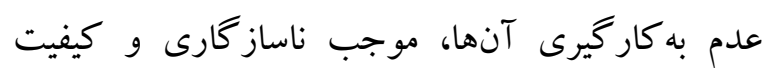

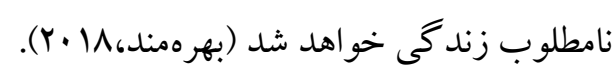

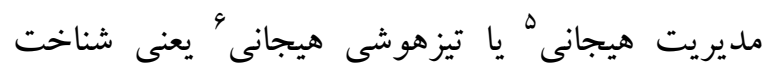

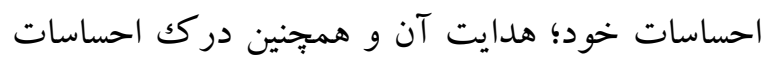

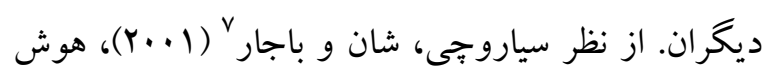
هيجانى ^عامل مؤثر و تعيين كننده در بر آيندهاى زندگى آنى واقعى مانند موفقيت در روابط بين فردى و اجتماعى و بهور كلى در كنشورى سلامت است. كلمن ( (.... هوش هيجانى را مهارتى مىداند كه دارنده آن مى تواند با كسب خود آكاهى، روحيات خود را كنترل نموده و خود مديريتى خود را بهبود بخشد و از طريق مديريت روابط به شيوهاى رفتار كند كه روحيه خود و ديخران را بالا ببرد و

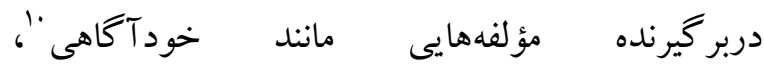

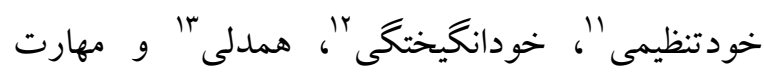

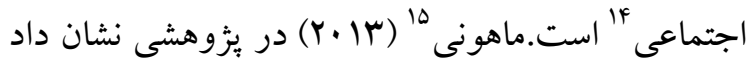
بالا بودن هوش هيجانى والدين، بهويزه مادر مىتواند از فرزندان آنها در موقعيتهاى مهم زندگى حمايت كند هن و يكك تجربه مثبت از صميميت با ديخران و موفقيت 19 تحصيلى براى كودكان فراهم كند. رينالدى و هوى

4- Jenaabadi, Azizi Nejad \& Mehdizade

5 - Emotional management

${ }^{6}$ - Emotional sharpness

7. Ciarochi, Chen \& Bajgar

${ }^{8}$ - Emotional intelligence

9 - Goleman

${ }^{10}$ - Self-awareness

${ }^{11}$ - Self-regulation

${ }^{12}$ - Spontaneity

${ }^{13}$ - Sympathy

${ }^{14}$ - Social Skill

15 - Mahoney

${ }^{16}$ - Rinaldi \& Howe
مقله مه

در جرخه تحول آدمى دوره مهمى وجود دارد كه بين دوره كودكى و دوره بزر گسالى قرار مى گيرد و به نوجوانى موسوم است. دورهاى كه شاخص بايان كودكى

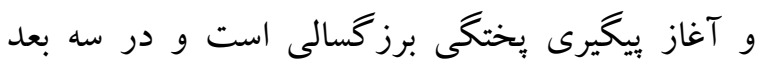
زيستى، روانى و اجتماعى است كه رابطه نزديكى با هم دارند نمايان مىشود. سالهاى نوجوانى مرحله مهم و برجسته رشد و تكامل اجتماعى و روانى فرد به شمار مى روند. در اين دوره انتخاب هدفهاى واقعى در زندگى رئ، استقلال عاطفى از خانواده، برقرارى روابط سالم با ديخران، كسب مهارتهاى اجتماعى لازم و مؤثر از

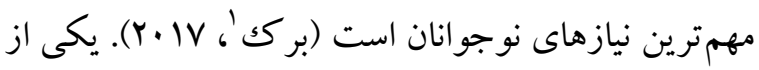
اين مهارتهاى مهم، كه نوجوان بايد از آن بهرهمند

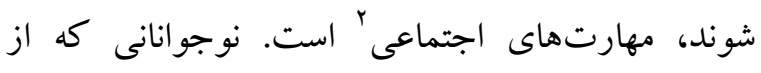

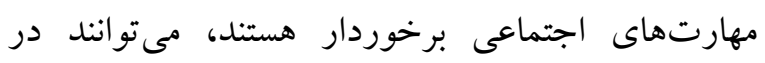
جامعه عقايد خود را بيان نموده و از نظرات خود دفاع كنند و با دوستان و اطرافيان ارتباط برقرار كنند و با آنان

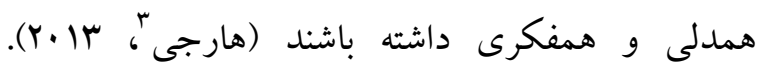
كودكان و نوجوانانى كه داراى مهارتهاى اجتماعى مناسب هستند، رفتارهايى از خود نشان مىدهند كه منجر به بيامدهاى مثبت روانى - اجتماعى نظير يذيرش توسط همسالان و رابطه مؤثر با ديخران مىشود (يوسفى، Y.19). از جمله مؤلفه هاى مهارتهاى اجتماعى مى توان به برقرارى دوستىهاى متناسب، نوعدوستى، هويت يابى، توجه و مراقبت از خود در كنار ديخران، مهارتهاى اوليه در برقرارى ارتباط، ارتباط با غريبهها، مهارتهاى جراتورزى و توانايى كفتن (انه)، شناسايى حقوق خود و ديخران و قدردانى از ديخران اشاره كرد (جنآبادى،

\footnotetext{
1- Berk

2- Social skills

3. Hargie
} 
هوش هيجانى بالا، روابط غير كلامى را بهتر درك مى - ما

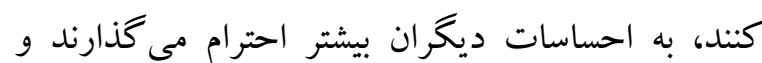
هوش هيجانى بايى در فرد، زمينه را براى بروز مشكلات

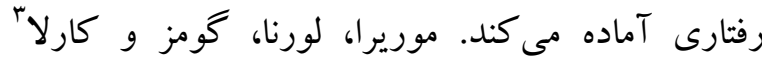

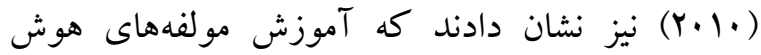
هيجانى به دانش آموزان موجب افزايش مهارتهاى

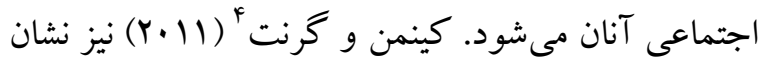
نشان دادند هوش هيجانى بالا موجب انعطافيذيرى و عملكرد بهتر فرد در محيط مى شود.

با توجه به اهميت فراوان مهارتهاى اجتماعى در جوامع امروزى و اهميت شكل گيرى اين مهارتها در دوران حساس و تعيين كننده نوجوانى، اهميت آموزش و تقويت اين مهارت در افراد على الخصوص نوجو انان امرى بديهى

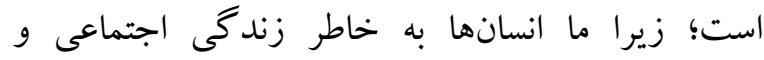
ارتباطات ميان فردى و فرا فردى به مهارتهاى اجتماعى درست و تقويت هوش هيجانى نيازمنديم. لذا مطالعه و يُزوهش در مورد مهارت اجتماعى هم جنبه بنيادى و توسعه علمى دارد و هم جنبه كاربردى بهمنظور بيشخيرى از آسيبهاى ناشى از روابط بين فردى ناصحيح. در واقع، مهارتهاى اجتماعى رفتارهاى جامعهيسندانهاى هستند كه در قالب فرهنگ و خردهفرهنگ توسط والدين و مربيان به كودكان و نوجوانان آموزش داده مىشوند، بنابر اين اهميت عملكرد والدين در اين بين روشن است؛ همجنين همانطور كه مطرح گرديد، هوش هيجانى از

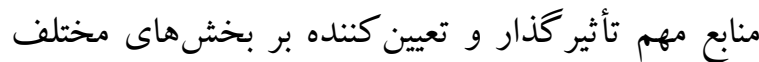
شخصيت و رفتار فرد در دورههاى مختلف زندكى است. بر اين اساس، يُوهشخر به دنبال بِاسخدهى به اين سؤال
نشان دادند كه ن تقويت هوش هيجانى مادران، ييشبينى كننده خوبى براى رفتارهاى اجتماعى ساز گارانه و تعاملات اجتماعى كودكانشان در نظر كرفته مىشود ـ در مطالعه ديخرى حنفى، محمد و حنيفه' نشان دادند كه ارتباط معنادارى بين هوش (Y.IV) هيجانى و عملكرد اجتماعى معلمين وجود دارد. بر بايه إزوهشهاى انجام شده، هوش هيجانى بهعنوان منبع مهم از منابع مؤثر بر مهارتهاى اجتماعى قلمداد مىشود براى مثال، داورنيا، حميدىنيا و اصغرنز الصراد (Y.IV) دارند، ارتباطات صميمى كمتر و احساس تنهايى بيشترى را تجربه مى كنند و در مقايسه با افراد عادى تمايل بيشترى به انزواى اجتماعى دارند. در مطالعهاى محمدزاده و خادمى اشكذرى (Y.IV) دريافتند كه آموزش مهارتهاى اجتماعى از راه بازىهاى گروهى بر بهبود مهارتهاى اجتماعى كود كان بيشدبستانى مؤثر است.

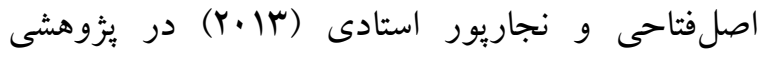
دريافتند كه بين هوش هيجانى با مهارتهاى اجتماعى رابطه معنادارى وجود دارد. جعفرى بلالمى، خليليان و

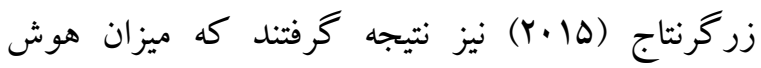
هيجانى قابل تغيير بوده و مىتوان آن را با آموزش مهارتهاى اجتماعى افزايش داد. حيدرىبور، مشهدى و

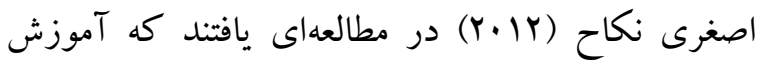
مهارتهاى اجتماعى بيشترين اثر بخشى را بر مؤلفهاى روابط بين فردى، روابط درون فردى، خلق عمومى، ساز گارى و كمترين اثربخشى را بر مؤلفه كنترل استرس روس از زيرمقياسهاى هوش هيجانى داشته است. همجينين

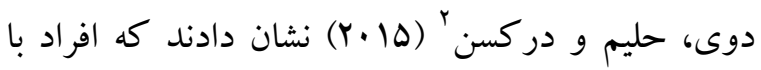

\footnotetext{
1. Hanafi, Mohamad \& Hanapiyah

2 - Dewi, Halim \& Derksen
}

3 - Moreira, Lorena, Gomes \& Carla

4. Kinmon \& Grant 
مربوط به يدر و مادر را دريافت و در تاريخ بعدى مشخص شده، تحويل دهد. بِ از جمع آورى برسشنامه،

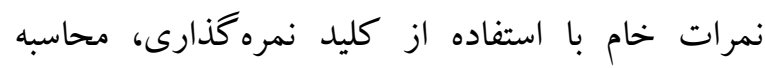
كرديد. از جمله رعايت ملاحظات اخلاقى در اين مطالعه مى توان به محرمانه بودن نام و اطلاعات دانش آموزان و

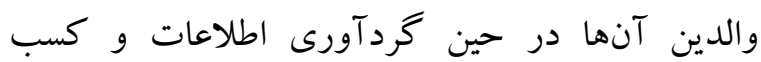
رضايت شخصى آنها جهت مشاركت در اين بثرهش را نام برد.

ابزار

يوسشنامه جمعيتشناختى: كه شامل اطلاعاتى در مورد سن، جنس، مقطع و پيايه تحصيلى براى نوجوانان و اطلاعاتى در مورد سن، ميزان تحصيلات و شغل والدين

يرسشنامه مهارتهاى اجتماعى نوجوانان'؛ اين برسشنامه

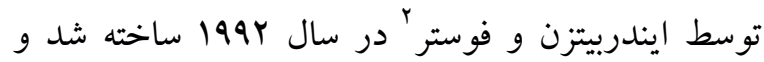

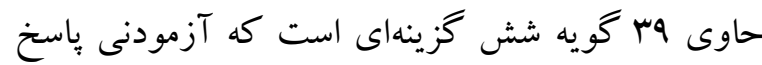
خود را در مورد هر عبارت در دامنهاى از ززينههاى (اصلاً درست نيست) تا (هميشه درست است))، ابزار مىنمايد. اين : يرسشنامه دو زيرمقياس رفتار نامطلوب اجتماعى "r و مهارتهاى اجتماعى " است. بر اساس اين

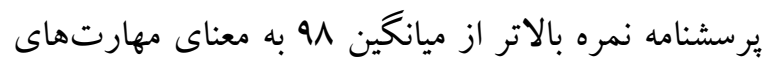
اجتماعى مطلوب است و نمره يايين تر آن به معناى رفتار نامطلوب اجتماعى است. بر اين اساس، نقطه برش اين

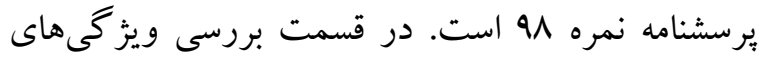
روان سنجى، يايايى اين :برسشنامه توسط ايندربيتزن و

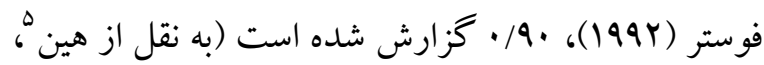

${ }^{1}$ - The teenage inventory of social skills (TISS)

${ }^{2}$ - Enderbitzen and Foster

${ }^{3}$ - Socially inappropriate behavior

${ }^{4}$ - Social skills

5 - Hein
است كه آيا مىتوان بر اساس هوش هيجانى والدين، مهارتهاى اجتماعى نوجوان را بيشبينى كرد؟

روش روش يثزوهش حاضر توصيفى از نوع همبستكى است كه بهور مقطعى در سال يهما انجام شد. جامعه آمارى اين تحقيق شامل كليه نوجوانان بين سا تا IV سال شهر تهران است كه والدين آنها در قيد حيات هستند. تعداد نمونه

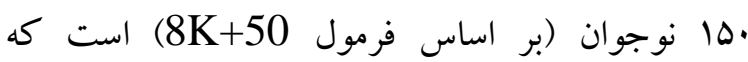
بهصورت نمونه گيرى تصادفى خوشهاى جندمرحلهاى انتخاب شدند. بدين منظور، بثزوهشخر با مراجعه به مناطق r Y Fانه آموزش و برورش شهر تهران بهصورت تصادفى، به جندين مركز و مجتمع آموزشى ارجاع داده شد. سيس از بين اين مراكز بهصورت تصادفى از دانش آموزان نوجوان و خانو ادههايشان كه تمايل به شركت در مطالعه داشتهاند، درخواست كرد تا برسشنامهاى مطالعه را تكميل كنند. ·r برسشنامه به دليل مخدوش بودن و عدم همكارى والدين كنار كذاشته شدند. معيارهاى ورود به يثزوهش عبارت بودند از توانايى به اختيار گذاشتن IV اطلاعات و تجربيات خود، قرار داشتن بين سنين لا تا تا سال و در قيد حيات بودن هم يدر و هم مادر. معيارهاى خروج نيز عدم همكارى يا مشاركت دانش آموزان يا والدينشان، سنين كمتر از سا و بالاتر از V و و يا اين كه يكى از والدين دانش آموز فوت كرده بودند، در نظر كرفته شد. بر اين اساس، يس از هماهنگَى با مسئولين

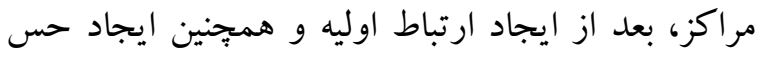
اعتماد نسبت به محرمانه بودن اطلاعات در بين نوجوانان و عدم نياز به ذكر نام و رعايت اصول رازدارى برسشنامهها توزيع شد. از هر نوجوان خواسته شد تا يرسشنامهاى 
ميزان همسانى آزمون سب گويهاى، در اجراى مقدماتى،

$$
\text { به روش آلفاى كرونباخ ه内/ • بوده است. }
$$

در اين بثزوهش براى تحليل دادهها از آمارههاى توصيفى درصد، فراوانى، ميانگين، انحراف معيار و ضريب برئ همبستخى ويرسون و در آمار استنباطى از تحليل رگر سيون جندمتغيره استفاده شد.

يافتهها براساس يافته هاى به دست آمده در خصوص توزيع نمرههاى جمعيتشناختى از •10 نوجوان شركت كننده در اين مطالعه تعداد •q نوجوان بِر و •9 نفر دختر و بيشتر در گرووه سنى لا تا IV سال قرار دارند. نتايج جدول شماره ا شاخصهاى توصيفى از جمله ميانگين، انحراف معيار، شاخصهاى كجى و كشيدگى را نشان مى دهد.

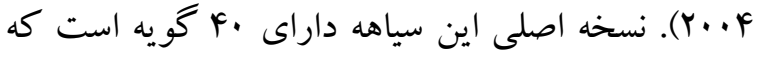
يكك گويه بهدليل عدم انطباق با فرهنگك ايران حذف شده است. اعتبار اين يرسشنامه را امينى (IrVA) در شهر تهران براى دانش آموزان دوم راهنمايى براى گز ارههاى مثبت و

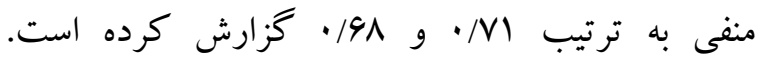
ارجمندى (rیr|) با استفاده از آلفاى كرونباخ جايايى اين يرسشنامه AF/ • به دست آورده است. بايايى اين برسشنامه كه توسط ايندربيتزن و فوستر طراحى شدهاست، براى

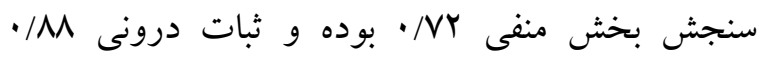
كزارش شده است (به نقل از فتحى آشتيانى، 9 ×. ب). يرسشنامه هوش هيجانى: اين آزمون توسط سيبريا

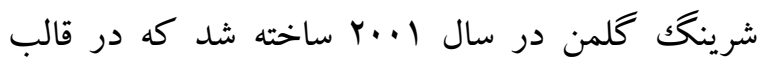
مقياس بنج گزينهاى ليكرت تنظيم شده است. فرم اصلى اين آزمون داراى •V كويه است و از دو قسمت تشكيل

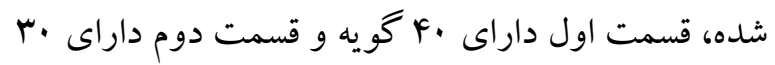

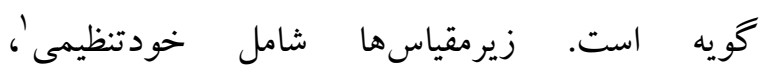

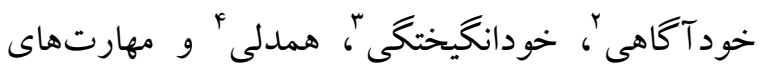
اجتماعى است. بر اين اساس نقطه برش اين يرسشنامه

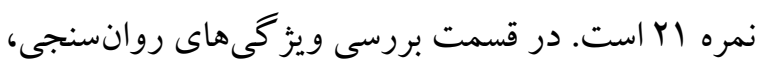
هايايى اين ويرسشنامه نمره •9/ • گزارش شده است؛ كه

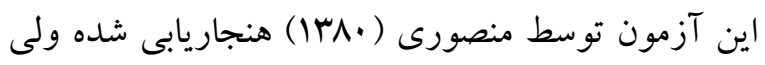
از قسمت دوم اين آزمون به علت عدم همخوانى داستان -

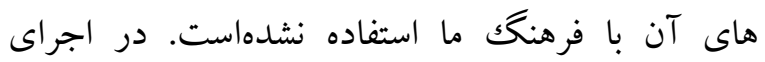

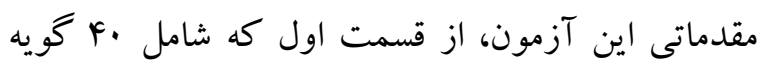
بود استفاده شده كه تعداد هفت سؤال بهعلت همبستكى اينى كم با نمره كل آزمون حذف شدهاند. سؤالاتى را كه براى اجراى نهايى در نظر گرفته شده اند سب گويه است.

1. Self-regulatory

${ }^{2}$ - Self-awareness

3 - Spontaneity

${ }^{4}$ - Empathy 


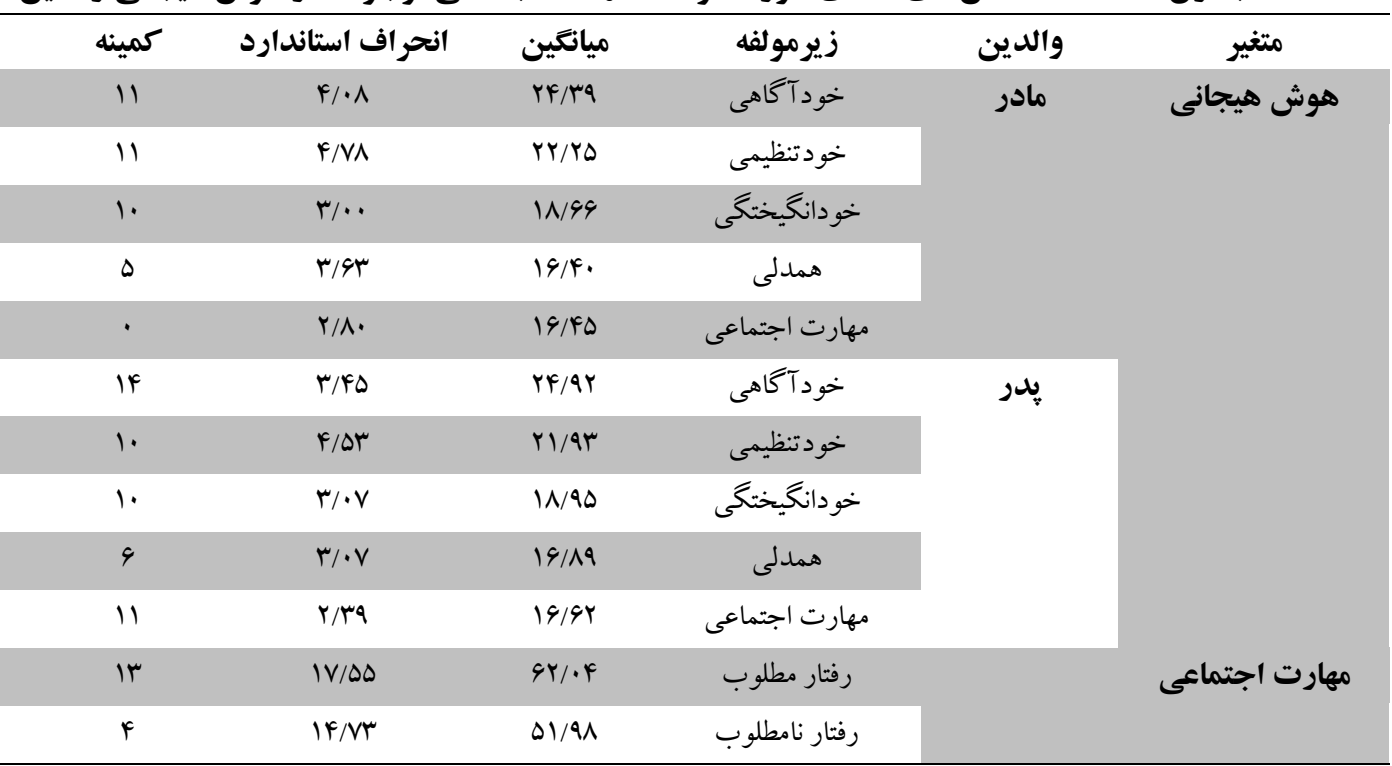

همانطور كه مشاهده مىشود توزيع نمرههاى گروه نمونه به توزيع نرمال ميل دارد. در جدول ب براى بررسى ميزان

\begin{tabular}{|c|c|c|}
\hline مهارت اجتماعى & مؤ لفه ها & متغير ها \\
\hline$\cdot / r Y V^{* *}$ & خود آكاهى & \multirow{5}{*}{ هوش هيجانى مادر } \\
\hline$\cdot / r \mu \cdot \cdot^{* * * * * *}$ & خود تنظيمى & \\
\hline $.1 \cdot 9$ & خودانگيختكى & \\
\hline$-\cdot / 1 \cdots$ & همدلى & \\
\hline$\cdot / r)^{*}$ & مهارت اجتماعى & \\
\hline$\cdot / 11 r$ & خود آ كاهى & \multirow{5}{*}{ هوش هيجانى يدر } \\
\hline$\cdot / \cdot \wedge r$ & خود تنظيمى & \\
\hline .1 .90 & خودانگيختخى & \\
\hline$-\cdot / \Delta \Delta \wedge *$ & همدلى & \\
\hline.$/ 119$ & مهارت اجتماعى & \\
\hline
\end{tabular}

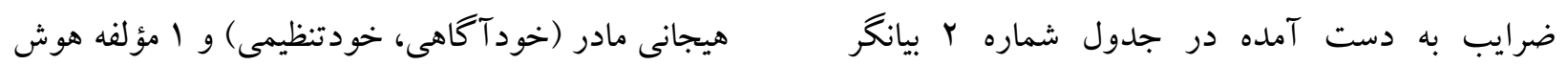
همبستگى بين متغيرهاى بيشبين و ملاكك است. جهت هيجانى بدر (همدلى) با مهارت اجتماعى نوجوان است؛

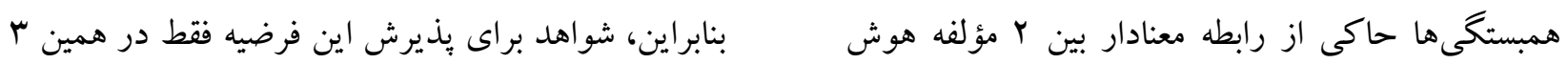


مشاهده نشد. همجنين در جدول ץ براى ييشينى مهارتهاى اجتماعى نوجوان بر اساس هوش هيجانى والدينشان از تحليل ركرسيون جندمتغيره استفاده شد.
مورد كافى است. وليكن، طبق نتايج بهدست آمده بين ديخر خرده مقياسهاى هوش هيجانى والدين و مهارت -

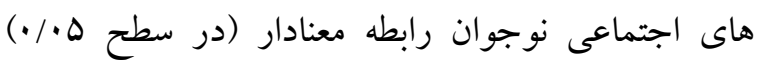

\begin{tabular}{|c|c|c|c|c|c|c|c|}
\hline معنادارى سطح & $\mathbf{R}^{2}$ & $\overline{\mathbf{R}}$ & $\mathbf{F}$ & مجذانغين & آزادى & مجذورات & شاخص \\
\hline.$/ . \cdot 1$ & . /FF & $\cdot /$ rVq & $9 / \cdot 1 r$ & Y99Y/WV9 & f & $1.901 / 119$ & مدل ركرسيون \\
\hline & & & & $\mathrm{rrV} / \mathrm{VW}$ & $1 F \Delta$ & GHFVV/AT & باقى مانده \\
\hline
\end{tabular}

وييشينى استفاده شود. علاوه بر اين، نسبت F محاسبه شده (9/10) در سطح اطمينان حداقل هو درصد معنادار است. بنابراين، مىتوان نتيجه گرفت كه بين متغيرهاى مورد مطالعه و متغير مهارت اجتماعى همبستخى معنادار

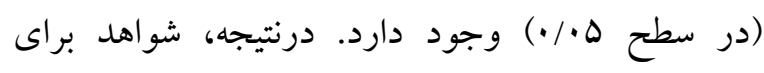
يذيرش اين فرضيه كافى است. همجنين در جدول أ براى ييشبينى مهارتهاى اجتماعى نوجوان بر اساس هوش

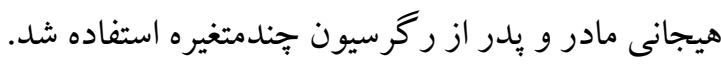

همانطور كه در جدول شماره r مشاهده مىشود، مقدار أبهآ $R^{2}$ درصد از واريانس متغير مهارت اجتماعى نوجوان توسط r متغير هوش هيجانى والدين تبيين مىشود.

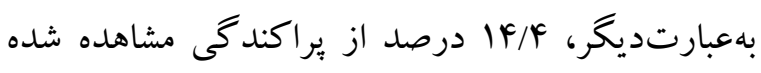
در متغير مهارت اجتماعى توسط اين متغيرها توجيه

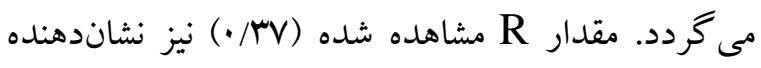
آن است كه مدل رگرسيون خطى حاضر مى تواند براى

\begin{tabular}{|c|c|c|c|c|c|c|c|c|}
\hline معنادارى سطح & $\mathbf{R}^{2}$ & $\mathbf{R}$ & $\mathbf{F}$ & مجذانكين & آزادى درجه & مجذورات & & شاخص \\
\hline \multirow[t]{2}{*}{.1 .19} &.$/ . r q$ &.$/ 19 V$ & ه/৭१ & $r M \Delta / \cdot V r$ & 1 & $r \wedge \Lambda \Delta / \cdot V r$ & مدل رگرسيون & هوش هيجانى \\
\hline & & & & $F N I / T W V$ & $1 F A$ & VIYFT/AGV & باقى مانده & مادر \\
\hline \multirow[t]{2}{*}{ - MAF } & $\cdot / \cdot \Delta$ & $\cdot / \cdot V r$ & . VGT & $r \Lambda \cdot / \cdot r \Lambda$ & 1 & $r \Lambda \cdot / \cdot r \Lambda$ & مدل رگرسيون & هوش هيجانى \\
\hline & & & & $F q \Lambda / r \cdot r$ & IFA & $V T V F N / q . r$ & باقى مانده & بֶدر \\
\hline
\end{tabular}

اجتماعى توسط هوش هيجانى مادر توجيه مىشود. مقدار

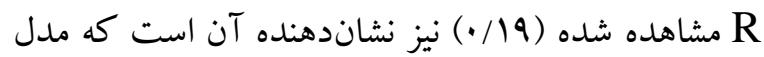
ركرسيون خطى حاضر مىتواند براى بيشبينى استفاده شود. علاوه بر اين، نسبت F محاسبه شده (ه/ه9) در سطح اطمينان حداقل هو درصد معنادار است. بنابراين،
همانطور كه در جدول شماره F مشاهده مىشود، مقدار

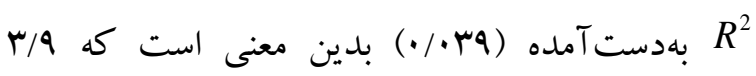
درصد از واريانس متغير مهارت اجتماعى نوجوان، توسط هوش هيجانى مادر تبين مى شود. بهعبارتديخر، درصد از براكندگى مشاهده شده در متغير مهارت 
محمدزاده و همكارش (Y.IV) مبنى بر اين كه آموزش مهارتهاى اجتماعى بر هوش هيجانى كودك تأثير گذار است، تقريباً همخوانى دارد. در تبيين اين فرضيه بايد گفت كه اخر بخواهيم مهارتهاى اجتماعى را برورش دهيم از همان ابتدا بايد

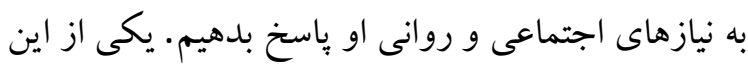
نيازها، بهخصوص در بين نوجوانان تقويت مهارتهاى بين فردى و افزايش اعتمادبهنفس براى ورود به جامعه بزرگكتر است. مهارتهاى اجتماعى مهارت هايى هستند كه از آنها بهمنظور برقرارى ارتباط و تعامل با يكديخر النه

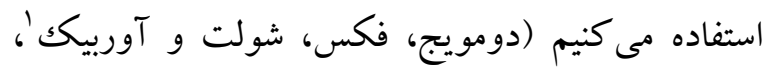

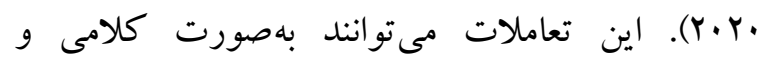
غير كلامى، از طريق حركات و اشارات بدن، زبان بدن و ظاهر شخصى ما اتفاق بيفتند. رشد و توسعهى مهارتهاى

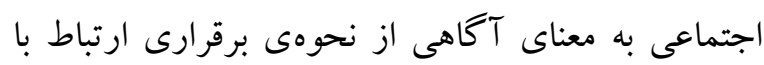

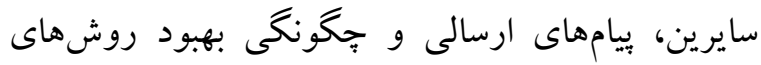
ارتباطى بهمنظور ايجاد روشى مؤثرتر و كاراتر براى برقرارى ارتباط است. از طرفى، هر فردى با ميزان

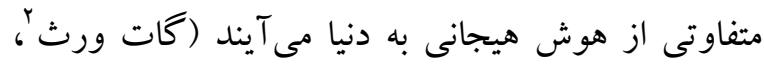

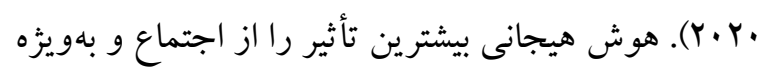
خانواده مىيذيرد و محيط خانواده اولين محل براى آموزش مهارتهاى هيجانى است. اين آموزش از طريق كفتار و رفتار مستقيم والدين با كودكان و همجينين الكوبردارى فرزندان از مهارتهاى هيجانى پيدر و مادر صورت مى گيرد و موجب مى شود كود كان در شناخت احساسات خود و ابراز مناسب هيجانات، يافنن روشهايى براى آرام كردن خود، كنترل احساسات ناخوشايند و

1. Mooij, Fekkes, Scholte \& Overbeek

${ }^{2}$ - Gutworth
مىتوان نتيجه كرفت كه بين متغيرهاى مورد مطالعه

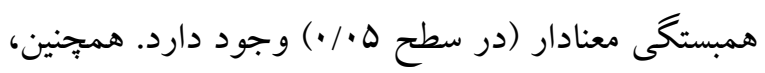

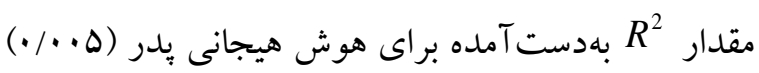
بدين معنى است كه ه/ • درصد از واريانس متغير مهارت اجتماعى نوجوان، توسط هوش هيجانى يدر تبيين

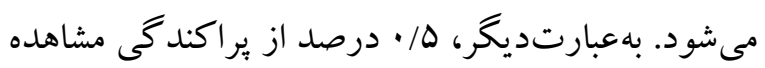
شده در متغير مهارت اجتماعى توسط هوش هيجانى بدر

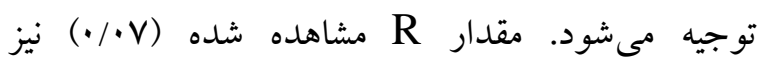
نشاندهنده آن است كه مدل رگرسيون خطى حاضر مى تواند براى ييشبينى استفاده شود. علاوه بر اين، نسبت

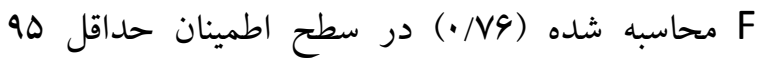
درصد معنادار است. بنابراين، مىتوان نتيجه گرفت كه بين متغيرهاى مورد مطالعه همبستكى معنادار (در سطح ه•• (•) وجود دارد. درنتيجه، شواهد براى يذيرش اين فرضيه كافى است. اين مطالعه با هدف بررسى رابطه بين هوش هيجانى والدين با مهارتهاى اجتماعى نوجوان انجام شد. همجنين درصدد بود تا ميزان مهارتهاى اجتماعى نوجوانان را بر اساس هوش هيجانى والدين بيشبينى كند. بر اين اساس نتايج نشان داد كه بين هوش هيجانى والدين و مهارت هاى اجتماعى نوجوان رابطه معنادارى وجود دارد. آزمون اين فرضيه از طريق تحليل رگرسيون

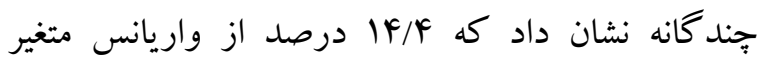
مهارت اجتماعى نوجوان توسط دو متغير هوش هيجانى والدين تبيين مىشود. اين بدان معنى است كه هوش هيجانى بالا در والدين باعث افزايش مهارتهاى اجتماعى نوجوانان مىشود. نتايج اين بزوهش با مطالعه 
(Y...)

مىدهد دو دسته هدف عمده دارد كه يك بخش آن اشاره به اهداف عاطفى دارد، يعنى بيدا كردن دوست و ايجاد روابط رضايتبخش و صميمى با ديخران؛ كه ارتباط اين نكته با هوش هيجانى كه يكك سازه جندعاملى است و از توانمندىهاى عاطفى، شخصى و اجتماعى تشكيل مىشود را روشن مىسازد (بريدى، ......). همجنين همانطور كه در تبيين و تعريف نظريات مرتبط با هوش هيجانى بيان شد (موريرا و همكاران، · · (Y)، فردى كه داراى هوش هيجانى بالا است، توانيى اين را دارد كه در مواجهه با جالشهاى محيطى از قابليتهاى عاطفى خود و ديخران، در رفتارهاى فردى و گروهى، براى كسب حداكثر نتيجه استفاده مفيد و مؤثر كند (اصل فاتحى و همكار، سا(Y) و افرادى كه از جنين موقعيت-

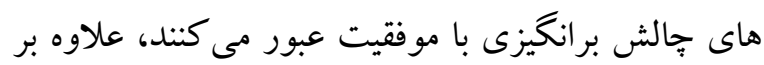
احساست خود، احساسات ديخران را نيز بهخوبى مى-

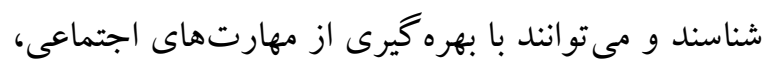
از يكك موقعيت جالشى به نفع خود و ديخران بهترين نتيجه را بكيرند. با توجه به نظريهاى ديخر، فردى كه هوش هيجانى بالايى دارد مىتواند كاميابى شخصى خود را به تعويق اندازد و ارتباط اين نكته با كنار آمدن با ديخران و ساز گارى در مهارتهاى اجتماعى روشن است (آبراهامز، بِانكوربو والديويا، بريمى، سنتوز، كيلونن، جان و دوفرويت؛

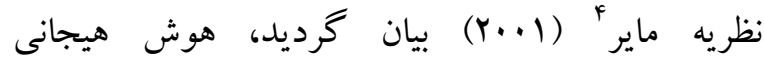
دربر گيرنده مهارتهاى درون فردى و برون فردى است كه آكاهى فرد از افكار و احساسات خويش، خود خردانى و توانايى كوش دادن، ارتباط برقرار كردن و همدلى با

${ }^{3}$ - Abrahams, Pancorbo Valdivia, Primi, Santos, Kyllonen, John, \& De Fruyt

${ }^{4}$ - Mayer
همجنين توانايى درك احساسات ديخران و همدلى با

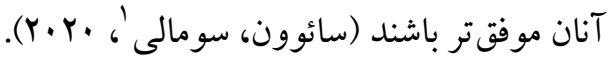
در مطالعات بيشين، مانند مطالعات حنفى و همكارش (Y.IV) هوش هيجانى را بر مهارتهاى اجتماعى فرد مورد بررسى قرار دادهاند، اما در اين بُزوهش محقق به دنبال رابطه هوش هيجانى در سطحى بالاتر از خود فرد، يعنى والدين بوده است كه طبق نتايج به دست آمده، هوش هيجانى والدين با مهارتهاى اجتماعى فرزند نوجوانشان ارتباط معنادارى دارد؛ اما در مورد هر كدام از والدين، جهت همبستگىها حاكى از رابطه معنادار بين Y مؤلفه هوش هيجانى مادر (خود آكاهى، خودتنظيمى) و 1 مؤلفه هوش هيجانى بدر (همدلى) با مهارت اجتماعى نوجوان است؛ بنابراين، شواهد براى يذيرش اين فرضيه فقط در همين r مورد كافى است. وليكن، طبق نتايج بهدستآمده؛ بين ديكر خردهمقياس هاى هوش هيجانى والدين و مهارت هاى اجتماعى نوجوان رابطه معنادار مشاهده نشد. طيف گستردهاى از مشكلات بين فردى، شامل مشكلات فرد در زمينهاى قاطعيت، مردم آميزى، اطاعت پيذيرى، صميميت، مسئوليتيذيرى و مهارگرى، علاوه بر ميزان توانايىهاى ديخر فرد، تحت تأثير هوش هيجانى نيز قرار

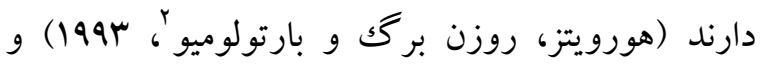
همانطور كه در استنباط آمارى جهت باسخ به اين سؤال

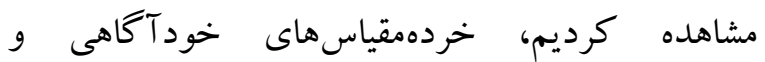
خودتنظيمى و همدلى والدين نيز با مهارتهاى اجتماعى مردي نوجوان ارتباط مثبت و معنادارى دارند. اين نتيجه با توجه به مبانى نظرى ئوهش منطقى بهنظر مىرسد، زيرا همانطور كه بيان شد، طبق نظر بريدى

\footnotetext{
1. Saowanee \& Sumalee

2 - Horowitz, Rosenberg \& Bartolomeo
} 


$$
\text { دمدارس راهنمايى و دبيرستان دخترانه مطهره و دبيرستان }
$$

\section{References}

Abrahams L, Pancorbo Valdivia G, Primi R, Santos D, Kyllonen P, John O \& De Fruyt F. (2019). Social-emotional skill assessment in children and adolescents: advances and challenges in personality, clinical and educational contexts. Psychological Assessment J, 31(4), 460-473.

Asle Fatahi B, Najjarpoor Ostadi S. (2013). A study of the relationship between emotional intelligence and self-esteem with social skills. Journal of Instruction \& Evaluation. 6(23):123-136. [Persian].

Bahremand A. (2018). Investigating the relationship between social life skills and components of students' political education, case study. Master thesis, Shahid Bahonar university, Kerman.

Berk Laura E. (2017). Development through the lifespan. 7ed, United States; Pearson.

Ciarochi JYC, Chen \& Bajgar J. (2001). Measuring emotional intelligence in adolescence. Personality \& individual differences joumal, 31; 1105- 1119.

Davamia A, Hamidi Pour R, Asghamejad Farid AA. (2017). Assessment of the relationship of attachment styles and emotional intelligence with love among couples. Joumal of fundamental of mental health, 19; 39-45.

Dewi ZL, Halim MS \& Derksen J. (2015). The BarOn emotional quotient inventory (EQ-i): development and psychometric adaptation in Bahasa Indonesia. Journal of Psychological Sciences, 1(2): 47-61.

Fathi ashtiani A. (2009). Psychological tests: the evaluation of personality \& mental health. Tehran: Besat [Persian].

Goleman D. (2000). Emotional intelligence: Issues in paradigm building. In D. Goleman, \& C. Chemiss (eds.). The Emotionally Intelligent Workplace: How to Select for, Measure, and Improve Emotional Intelligence in Individuals,
افرادى كه عقايد و ديد گاههاى و ارزشهايى متفاوت دارند را شامل مىشود. در مدل كُلمن نيز دو حوزه از ينج حوزه اساسى هوش هيجانى كه اشاره به تشخيص و درك

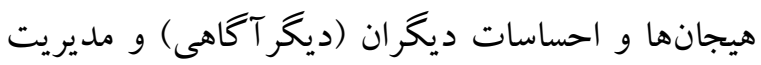
رابطه با ديخران (ديخرمديريتى) دارد در ارتباط با باس مهارت هاى اجتماعى است.

\section{نتيجه كيرى}

بهطور خلاصه، يافتهاى بثزوشش حاضر نشان داد كه ميزان مهارتهاى اجتماعى نوجوانان با هوش هيجانى والدينشان ارتباط دارد. يزوهش هاى علوم انسانى در هر مرحله به دليل عدم ييشبينى رفتارهاى انسانى و بيبحيده بودن ابعاد مختلف انسانى، با محدوديتهايى مواجه

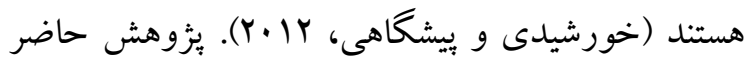
نيز، از اين امر جدا نبوده و يثزوهشكر با مشكلاتى روبهرو بود. ازجمله: مقطعى بودن مطالعه حاضر و عدم كنترل متغيرهاى تعديل گر؛ اما يافتهاى اين بثروهش اغلب نتايج

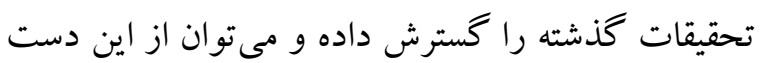
مطالعات بر روى نمونهاى بالينى و غير بالينى ديخر مطالعات اين جنينى انجام داد؛ بنابراين، به محققان براى يثزوهشهاى آتى توصيه مىشود تا در اين زمينه مطالعاتى بر روى گروههاى مختلف نوجو انان انجام دهند حتى در ائى بين اقوام مختلف ايرانى نيز مطالعات به اين سبك مى تواند منجر به شناسايى عوامل مؤثر بر مهارتهاى اجتماعى شود كه ريشه در هوش هيجانى والدين آنها

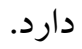

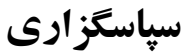

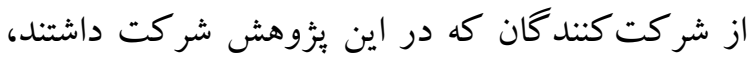
دانش آموزان و والدينشان از مجتمع آموزشى ناوك، 
Groups, and Organizations. San Francisco, CA: Jossey-Bass.

Gutworth MB. (2020). A meta-analysis of virtual reality training programs for social skill development. Computers and Education, 144, [103707].

Hanafi WN, Mohamad M, Hanapiyah Z. (2017). Measuring the influence of emotional intelligence toward teacher job performance. International joumal of business management. 2(7): 15-27.

Hargie O, Saunders k \& Dickson D. (2013). Social skills in interpersonal communication. the University of Michigan; Croom Helm.

Heidarpour M, Mashhadi A, Asghari Nekah SM. (2012). The effectiveness of social skills training on emotional intelligence of physicaldisabled persons. Research in Rehabilitation Sciences. 8(3): 571-580. [Persian].

Hein S. (2004). Short definition of emotional intelligence, Emotional Intelligence Homepage.

Jafaribalalami N, khalilian AR, Zargamataj T. (2016). The effect of instructing emotional intelligence capabilities on improving social skills among students of Mazandaran university. Teb va Tazkiye joumal. 24(4): 81-90. [Persian].

Jenaabadi H, Azizi Nejad B, Mehdizade A. (2015). Effect of teaching critical thinking on social skills growth of medical sciencessStudents. Educ Strategy Med Sci. 8 (2):69-73.

Khorshidi GH, Pishgahi S. (2012). Capacities \& obstacles for developing interdisciplinary humanities. Interdisciplinary studies in the humanities. 4(2): 1-15.

Kinman G \& Grant L. (2011). Exploring stress resilience in Trainee Social Workers: The role of emotional and social.

Mahoney G. (2013). Working class mothers and school life: exploring the role of emotional Capital. International Joumal of Psychology, 18 (3), 10-13.

Mohammadzadeh Z, khademiashkzari M. (2017). Teaching social skills through group games with the control of mothers' emotional intelligence quotient. Educational Psychology. 13(43): 75-99. [Persian].
Mooij BD, Minne F, Scholte RHJ, Overbeek G. (2020). Effective Components of Social Skills Training Programs for Children and Adolescents in Nonclinical Samples: A Multilevel Meta-analysis. Clinical Child and Family Psychology Review. (9): 1-15.

Moreira P, Crusellas L, Sa I, Gomes P, Matias C. (2010). Evaluation of a manual, based program for the promotion of social and emotional skills in elementary school children: results from a 4-year study in Portugal. Health Promotion International, 25(3), 309-317.

Rinaldi CM, Howe N. (2012). Mothers` and fathers' parenting styles and association with Toddlers 'extemalizing, intemalizing, and adaptive behavior. Early Childhood Research Quarterly, 27(2), 266-273.

Saowanee P \& Sumalee C. (2020). The development of social emotional leaming programs in a cross-cultural elementary classroom, Intemational Journal of Innovation and Learning, Inderscience Enterprises Ltd, 27(1), 58-78.

Yousefi M, Amirimajd M, Bazaian S. (2016). The effectiveness of social skills training on shyness in Eeementary school girl students. Abhar behavioral sciences joumal. 29: 61-74. 